\title{
THE PLATEAU PHASE OF GROWTH \\ OF THE L-M STRAIN MOUSE CELL IN A PROTEIN-FREE MEDIUM
}

\section{PROLONGATION OF THE PLATEAU PHASE BY SUPPLEMENTAL GLUCOSE ${ }^{1}$}

D. J. MERCHANT and C. R. EIDAM ${ }^{2,3}$

Department of Microbiology, The University of Michigan, Ann Arbor, Mich., U.S.A.

Received March 2, 1964

WHEN L-M strain [5] mouse cells are grown in suspension and the culture is allowed to develop without medium renewal, a growth curve is obtained which is similar to that seen with a non-selected population of almost any single cell organism under similar conditions $[6,8,9,13]$. Population doubling time varies with the nature of the medium used [7]. In mixture 199 plus 5 per cent horse serum it is approximately $30 \mathrm{hr}$. When yeast extract and protein hydrolysates are added this may drop to $24 \mathrm{hr}$ or below, while in protein-free media such as 199 plus peptone or in non-supplemented Eagle basal medium the doubling time is around $35-40 \mathrm{hr}$ or $50-60 \mathrm{hr}$ respectively.

During the lag and logarithmic phases of the growth cycle of this cell line, glucose is taken up and utilized at a rapid rate. Within a short time after the culture has entered the stationary phase glucose and lactate are exhausted from the medium [11]. The initial concentration of glucose in the medium has no determining effect on growth rate and little effect on the final population density over the concentration range of 10 to $200 \mathrm{mg} \%$ [10].

After a culture has entered the stationary growth phase, and glucose is exhausted, there is a continuing drop in the mean cell volume and in viability. Generally within five to seven days the viability has dropped to 30 or 40 per cent and rapid cell destruction ensues [8].

From the above observations we surmised that while glucose perhaps is

1 This work was supported in part by Grant CA-03729 from the USPHS and by Parke, Davis and Company, Detroit, Mich.

2 Present address: Child Research Center of Michigan, 660 Frederick St., Detroit, Mich.

3 Part of this material is from a dissertation submitted in partial fulfillment of the requirements for the degree of Doctor of Philosophy at The University of Mich. 
not the limiting factor in determining either total synthesis or the final population level in a given system it may be extremely important for cell maintenance. The observations noted would support the hypothesis that with exhaustion of glucose and other readily oxidizable substrates, cells may be forced to rely on endogenous metabolism.

In the experiments reported here supplementation of glucose at the onset of plateau, was shown to have a sparing action on the cells. Decrease in cell size and loss of viability were delayed and enhanced synthetic activity was noted.

\section{MATERIALS AND METHODS}

L-M cells were harvested from cultures in the late logarithmic growth phase and were resuspended in fresh medium at a concentration of $2-3 \times 10^{5}$ cells per ml. The medium used was modified synthetic mixture 199 [2] supplemented with 0.5 per cent Bacto-peptone, ${ }^{1} 0.1$ per cent of methylcellulose ${ }^{2}$ and 0.025 per cent Darvan No. $2^{3}$ [2]. One hundred $\mathrm{ml}$ of cell suspension was distributed into each of several $500 \mathrm{ml}$ screw-capped erlenmeyer flasks. These were incubated at $35^{\circ} \mathrm{C}$ on a rotary shaker at $110 \mathrm{rpm}$ without gassing. In later experiments cells were grown in $900 \mathrm{ml}$ capacity modified spinner flasks [2] which were mounted on a multiple spindle magnetic stirrer. ${ }^{4}$ To each flask was added $500 \mathrm{ml}$ of cell suspension containing $4 \times 10^{5} \mathrm{cell} / \mathrm{ml}$. A cotton filter on one side port of the flasks gave interchange with the atmosphere.

Supplemental glucose was prepared as a 10 per cent solution in distilled water and was sterilized by autoclaving at $121^{\circ} \mathrm{C}$ for $15 \mathrm{~min}$. Five ml aliquots were stored as frozen stocks until ready for use.

Cell number and cell size distribution were determined using a Model A Coulter electronic cell counter. ${ }^{5}$ The threshold dial settings arbitrarily were divided into four categories or ranges based on the previous observations of Merchant et al. [8]. Those cells included by the threshold range of 5-25 were of the smallest variety and were almost exclusively non-viable. Those included in the range of 25-45 were the progeny of recent cell division or those in the early part of the intermitotic cyle. The range of 45-65 included cells nearing completion of their synthetic activity and those in the range of 65 or greater represented cells ready for cell division. Viability was measured by the erythrosin B dye-exclusion technique [12].

\section{RESULTS}

In the first series of experiments replicate cultures were prepared in erlenmeyer flasks. To each of two such flasks glucose was added as a supplement

1 Difco Laboratories, Detroit, Michigan.

215 CPS, reagent grade, Dow Chemical Co., Midland, Michigan.

${ }^{3}$ A polysulfonic acid dispersing agent, R. T. Vanderbilt Co., New York City.

4 Eberbach Corporation, Ann Arbor, Michigan.

5 Coulter Electronics, Hialeah, Florida. 
on day 6 , at a concentration of $2 \mathrm{mg} / \mathrm{ml}$. These cultures and replicate controls were followed for an additional 31 days without medium renewal or supplementation. No attempt was made to adjust $\mathrm{pH}$ though this never fell significantly below 6.8 as judged by color of the phenol red indicator.

A typical experiment is presented in Fig. 1. It will be seen that, while the

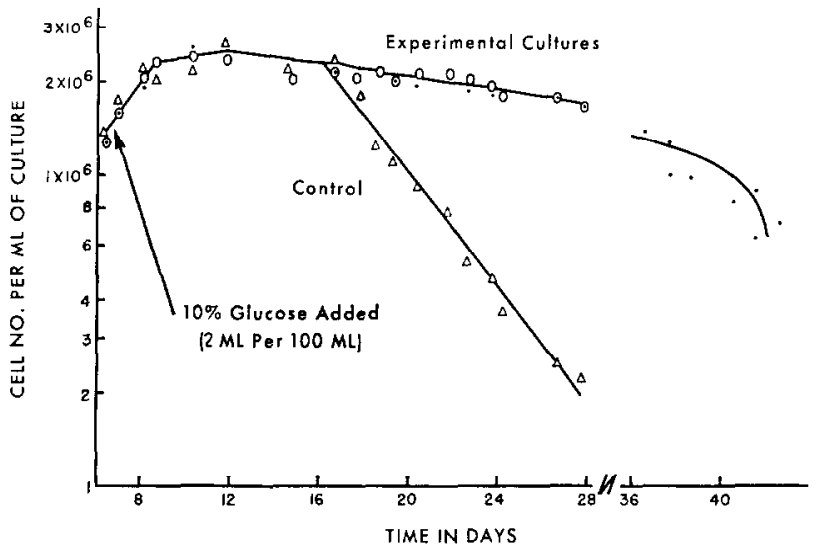

Fig. 1.- Effect of added glucose on maintenance $L-M$ strain cells in suspension culture.

control culture followed a normal pattern of development, maintenance and subsequent degeneration, the cultures supplemented with glucose were maintained for a much longer period. Both total cell number and cell viability decreased gradually over a period of many days in contrast to the precipitous drop in the control cultures. Though not shown in this condensed graphic presentation, the numbers of cells in the glucose supplemented cultures showed an almost rhythmic cyclic pattern during the period of gradual decline.

In further experiments cells were grown in modified spinner flasks. Fig. 2 shows growth curves typical of five experiments employing a minimum of 4 replicate cultures each in which glucose was added at a level of $1 \mathrm{mg} / \mathrm{ml}$ in the late logarithmic growth phase. This was just half the amount added in earlier experiments.

In the series illustrated, the viability of the control culture dropped from 96 to 69 per cent (a difference of 27 per cent) in $120 \mathrm{hr}$, whereas the culture receiving glucose showed only a 6 per cent decrease of viable cells during the same interval. Viability of the experimental culture remained relatively high for an additional $56 \mathrm{hr}$ while that of the control culture dropped rapidly. Cell number tended to increase slightly in the experimental culture. 
As seen in Fig. 3, the relative cell size distribution of the experimental population, during the plateau phase, showed a cyclic increase and decrease of the three classes of cells which were actively engaged in protein and nucleic acid synthesis. This cyclic phenomenon was observable after $150 \mathrm{hr}$ in culture. On the other hand the smallest class of cells, which represented

Fig. 2.--Effect of additional glucose on the viability of L-M cells during plateau phase.

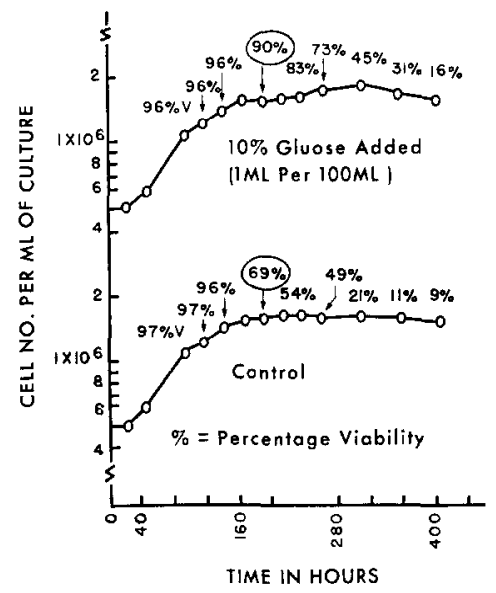

the non-viable portion of the population, remained relatively constant for many hours and then increased steadily in size until the termination of the experiment. This confirmed the observation in the first series of experiments that cell division was occurring on a small and decreasing scale and was paralleled by lysis of a small percentage of cells. Attempts were made to detect cell division microscopically but technical difficulties in handling cells from suspension for cytologic work made this unsuccessful. The control culture shows the usual pattern of plateau with a steady decrease in the percentage of larger cells and a corresponding increase in small cells. This shift is delayed by glucose supplementation. In most cultures there was no rapid decline in cell number until viability reached zero.

The termination of the plateau phase was characterized by low viability and complete shift to cells of small size. Characteristically, at this point, rapid cell destruction occurred accompanied by a shift to an alkaline $\mathrm{pH}$. It should be noted, however, that in this system cell destruction may be delayed for some time after viability has reached zero. Viability decreases as average cell size decreases, but not necessarily at the same rate. 


\section{DISCUSSION}

The range of cell sizes in a population shifts from a random distribution, which is characteristic of a logarithmically growing culture to a predominance of small cells after $48-72 \mathrm{hr}$ in the plateau phase. The reason for the

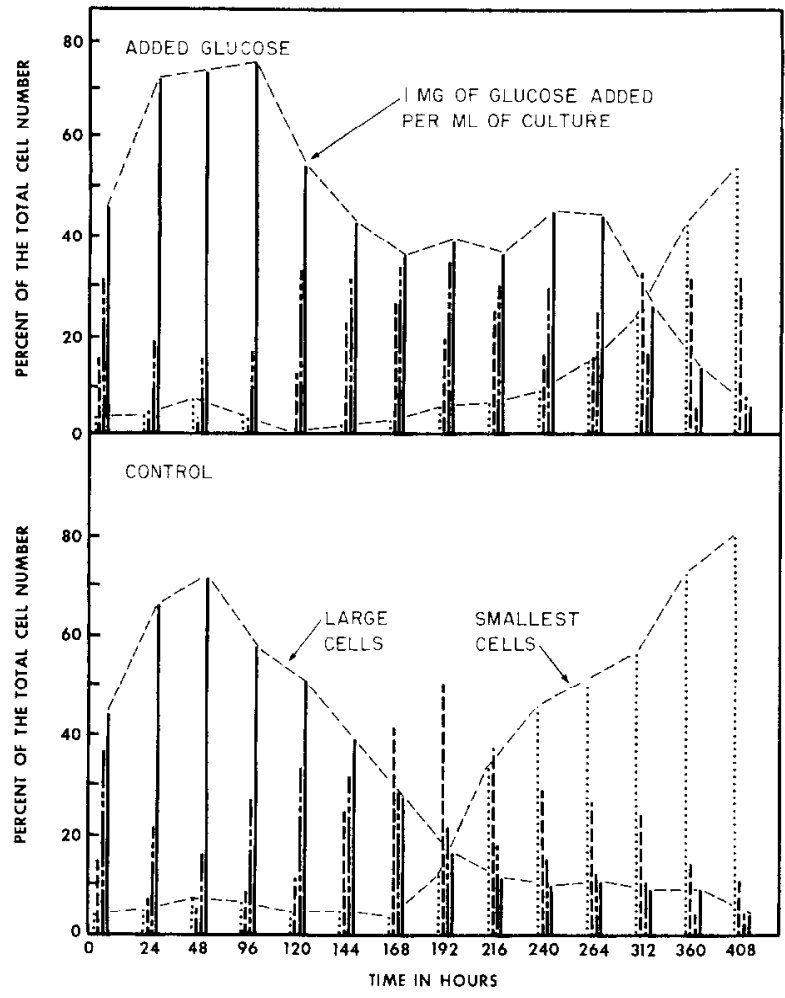

Fig. 3.-Effect of additional glucose on the cell size distribution of L-M cells during plateau phase. Lines indicate percent of the total cell number found in four different size categories. Line ..... in each group represents cells recorded with the dial setting of threshold 5-25 on a Model A Coulter electronic cell counter, line - - - - , threshold $25 \sim 45$, line threshold 45-65, line threshold 65 .

decrease in mean cell volume during this period appears to be twofold. It has been demonstrated that a significant increase in cell number occurs after cessation of increase in dry weight and of protein nitrogen [8], in other words, after rapid synthesis ceases. As a result a portion of the cells reaching maturity divide but cannot increase in volume. Hence the random distribution is skewed in the direction of the smaller daughter cells. A second factor is related to the previous observation that glucose is exhausted $[11]$ and the residual population probably reverts entirely to endogenous metabolism thereby reducing the structural and functional units of the cell until a point 
is reached where cell integrity no longer can be maintained. In other words death occurs by starvation. Glucose added to the culture at the onset of the plateau phase delays this phenomenon by serving both as an energy source and as a precursor of protein and nucleic acid synthesis $[1,3,4]$.

In the presence of supplemental glucose some cell division continues as detected by the cyclic increase and decrease of small to large cells (the three largest classes of cells in Fig. 3). At the same time a small portion of cells becomes non-viable and the increase in non-viable cells parallels closely the increase of the smallest cell type (Figs. 2 and 3). The decrease in viability and the accumulation of small cells does not occur until many hours after the onset of plateau. Thus at $240 \mathrm{hr}$ the viability had dropped only 13 per cent in the supplemented culture (Fig. 2).

In a glucose depleted culture, on the other hand, the increase in small cells and the loss of viability progresses much more rapidly. Viability had dropped by 28 per cent within $192 \mathrm{hr}$ and by 43 per cent at $240 \mathrm{hr}$ (Fig. 2). This was paralleled by a sharp increase in the smallest cell type beginning between 168 and $192 \mathrm{hr}$ (Fig. 3).

From the onset of plateau (approximately $96 \mathrm{hr}$ ) there was a steady decline in the number of cells in the two larger categories in the unsupplemented culture. This was most precipitous in the largest class. To $168 \mathrm{hr}$ the number of very small cells had remained constant and there was little change in viability. During this same interval, however, the smallest group of viable cells had increased significantly, paralleling the decrease of the two larger categories. No cycling was observed in this culture as compared to the culture supplemented with glucose. While this does not rule out the possibility of a very low level of population renewal it would seem quite unlikely that this occurred to a significant extent.

In most experiments the level of the total DNA recovered remained constant or increased slightly during the plateau phase [2]. This implies that cell division was restricted, but in a glucose supplemented culture, the detection of radioactivity in DNA indicates the ability of the cells to utilize glucose in synthesis and replenishment of this material in an otherwise depleted medium [3].

The fact that the plateau phase is extended in the presence of supplemental carbohydrate suggests that this phase results more from the exhaustion of other nutrients than from the accumulation of toxic products in the system. Moreover, the observation that logarithmic growth does not resume after the addition of glucose indicates that it is not the sole limiting factor responsible for onset of the plateau phase. Furthermore high levels of glucose are 
not required for the maintenance of viability and metabolic activity as suggested by the excess of carbohydrate that remains in the medium throughout the plateau phase in supplemented cultures [3].

We feel that mature populations of cells maintained for prolonged periods in stationary phase more closely resemble somatic cells in the adult in vivo than does the usual tissue culture system. Prolonged maintenance of dense populations of cells in a viable and metabolically active state without accompanying rapid proliferation is desirable for many kinds of studies. The system reported here differs from most maintenance situations in that equilibrium is established internally rather than by having arbitrary limiting factors imposed from without. From the experiments described it would appear that while the availability of readily utilizable exogenous energy sources may not be the determining factor in controlling cell growth it may he quite critical in cell maintenance.

\section{SUMMARY}

Supplementation of glucose at the beginning of the plateau phase has been shown to extend the duration of this phase by as much as fourfold in suspension cultures of L-M strain mouse cells in a protein-free medium.

The role of glucose seems to be, at least in part, one of sparing action on the cells by providing a readily available energy source. Continued cell synthetic activity also may be promoted. No net increase in cell numbers occurred.

Decrease in the average cell size and loss of viability were significantly delayed while a cyclic pattern of cell size changes suggested a low level of population turnover and renewal.

\section{REFERENCES}

1. Eagle, H., Barban, S., Levy, M. and Schulze, H. O., J. Biol. Chem. 233, 551 (1958).

2. Eidam, C, R. and Merchant, D. J., Expll Cell Res. 37, 132 (1965).

3. - ibid. 37, 147 (1965).

4. Fischer, A., J. Natl Cancer Inst. 13, 1399 (1953).

5. Hsu, T. C. and Merchant, D. J., Natl Cancer Inst. 26, 1075 (1961).

6. Iwamura, R. and Myers, J., Arch. Biochem. Biophys. 84, 267 (1959).

7. Merchant, D. J. and Hellman, K., Proc. Soc. Exptl Biol. and Med. 110, 194 (1962).

8. Merchant, D. J., Kuchler, R. H. and Munyon, W. H., J. Biochem. Microbiol. Tech. Eng. 2, $253(1960)$.

9. Monod, J., Ann. Rev. Microbiol. 3, 371 (1949).

10. Munyon, W. H., Personal communication.

11. Munyon, W. H. and Merchant, D. J., Expll Cell Res. 17, 490 (1959).

12. Phillips, H. J. and Terryberry, J. D., Exptl Cell Res. 13, 341 (1957).

13. Prescott, D. M., Exptl Cell Res. 12, 126 (1957). 